\title{
1. Introduction: knowledge, desire and power in Western representations of China's rise
}

... there is no knowledge-political or otherwiseoutside representation.

Homi Bhabha $^{1}$

... the real issue is whether indeed there can be a true representation of anything, or whether any and all representations, because they are representations, are embedded first in the language and then in the culture, institutions, and political ambience of the representer.

Edward W. Said ${ }^{2}$

... the facts of history never come to us "pure", since they do not and cannot exist in a pure form: they are always refracted through the mind of the recorder. It follows that when we take up a work of history, our first concern should be not with the facts which it contains but with the historian who wrote it.

E. H. Carr $^{3}$

\section{THE RISE OF THE ‘CHINA'S RISE’ LITERATURE}

For centuries, China has been a fixture in the Western imagination, variously described as the 'land of milk and honey', a 'sleeping giant', the 'sick man of Asia', the 'Yellow Peril' and the 'Red Menace'. Now fast emerging as a global powerhouse, this once 'sleeping giant' has once again come to preoccupy the Western consciousness. With its profound yet uncertain impact on regional and global power balance, a new growth field of watching China's international relations (IR) has gathered pace, characterised in particular by an explosion of literature on China's rise. ${ }^{4}$ Indeed, not a day goes by without one being reminded of the 'awakening', 'rise', 'rising', 'ascent', or 'domi- 
nance' of China. This expanding literature has been fittingly called the 'China's rise literature'.

That much has been said and written on China's rise is no surprise. Yet, what is puzzling is that little seems to have been explicitly said and written about this particular genre of China literature, which itself is nothing short of a phenomenon. Whilst many in the China watching community are taken up with the 'empirical' issues of what China is and what its rise means, few seem to have seriously contemplated what this growth field is all about. This book, in turning a critical gaze on this discursive phenomenon, aims to address this neglected but critical issue along with some attendant questions. What, for instance, is the study of China's international relations? Where does it come from? What is it exactly that we are doing when we purport to merely observe China's rise? Why does China watching in IR rarely deviate from certain enduring modes of representation, such as 'threat' and 'opportunity'? And what roles do those modes of representation play in both our understanding of, and our interaction with, China?

\section{CHINA WATCHING RARELY WATCHES ITSELF}

These questions may strike many scholars as trivial and superfluous, if not odd. To others they may immediately smack of empty epistemological speculations - surely China watching is about uncovering and accumulating knowledge on China, with its core business centred on understanding key empirical issues that really matter in China's relations with the world, issues ranging from power, capabilities, interests, intentions and identity to foreign policy, grand strategy and behaviour patterns. Thus, where periodically there have been welcome attempts to reflect on the 'state of the art' in China watching, ${ }^{6}$ the main objectives of those reflections have been to help 'build cumulative knowledge' and to explore some 'potential avenue for new research'. ${ }^{7}$ Predictably, such stocktaking has been largely positive and selfcongratulatory in tone. At the 'Trends in China Watching' conference held at George Washington University in 1999, participants seemed genuinely impressed by 'the diversity of approaches and perspectives' in the field, which they regarded as 'the most valuable asset China watchers have today'. ${ }^{8}$ Two prominent experts on Chinese foreign policy, Robert Ross and Alastair Iain Johnston, would concur. In their edited book on new directions in this China field, they claim that China scholars are now in a better position to meet the growing demand for sophisticated analysis on China's foreign policy. ${ }^{9}$ For still others, 'the field is doing a good job of keeping up with and interpreting fast-changing developments in China, and... the international "state of the field" can be judged to be healthy and growing,. ${ }^{10}$ 
Growing this field may be, but healthy it seems not. According to Roland Barthes, a 'healthy' sign should be honest about its own arbitrariness. Rather than pretending to be 'natural' or 'objective', it admits 'its own relative, artificial status'. 11 Judging by this requirement, the IR branch of China watching appears far from healthy. As just noted, amidst an ongoing celebration of its scientific contribution to China knowledge, this field has thus far shown little critical self-reflection required of a healthy sign. True, some China watchers are aware of the limits of their own work and even the problematic status of China watching as objective knowledge. G. John Ikenberry and Michael Mastanduno lament that 'the rich comparative and foreign policy scholarship on China' is 'under-theorized', and they call for its better engagement with the 'theoretical insights of international relations'. 12 David Shambaugh notes that while 'rich in monographic literature on different periods and bilateral interactions', the field 'lacks studies with aggregate and reflective perspectives'. ${ }^{13}$ In a semi-autobiographical reflection on China watching, Richard Baum admits that objectivity in China studies is 'an elusive grail' and that our understanding is often coloured by 'personal sentiments and emotions'. ${ }^{14}$ Such reflections, however, often limited in scope and made in passing, remain a rare commodity.

Such a problem is not unique to IR China watchers. Anthropologists are said to be skilled at 'probing other cultures' but often fall short of reflecting on their own. ${ }^{15}$ Likewise, political scientists, always ready to expose the political and ideological baggage of practitioners, seldom subject their research to similar scrutiny. ${ }^{16}$ All this, it seems, reveals a common pitfall in human understanding itself: 'The Understanding, like the Eye, whilst it makes us see, and perceive all other Things, takes no notice of it self: And it requires Art and Pains to set it at a distance, and make it its own Object', thus wrote John Locke. ${ }^{17}$ If human understanding needs to better understand itself, China watching as a particular subset of human understanding should also make itself its own object and allow for self-watching.

In research, watching the self may come in different forms. Autoethnography, for one, calls for the explicit use of the self as a methodological resource in the production of knowledge. ${ }^{18}$ In this book, by 'self' I mean not literally the personal experience of China watchers (though that is no doubt fascinating in itself), but rather their collective knowledge products, the broader intellectual, socio-political context of their knowledge production, and their underlying ideas and imaginations of themselves as the knowing subject. Thus defined, self-watching in China studies requires not only a methodological shift, but also an ontological and epistemological rethinking (if we suppose that the former can ever be separated from the latter).

A key suspect for the conspicuous absence of healthy self-reflection in China watching has to be the ever-appealing positivism, an epistemological 
glue which helps hold an otherwise 'argumentative China watching community' together. ${ }^{19}$ As an extremely influential theory of knowledge, positivism presupposes the existence of an objective reality 'out there', independent of our thought but ultimately amenable to scientific analysis. ${ }^{20}$ Crucially, claiming to have reached 'the end of the theory of knowledge', positivism performs 'the prohibitive function of protecting scientific inquiry from epistemological self-reflection' ${ }^{21}$ In this way, the epistemological question of how we know what we know seems no longer necessary. Insisting on a clear distinction between 'observable facts and often unsustainable "speculations about them", David Martin Jones is irritated by the postcolonial effort of "exposing representation in literary "texts" or in film and music rather than addressing the empirical realm of social facts'. ${ }^{22}$

Rallying around the positivist tradition, most China watchers in the IR field treat China as something made up of such observable facts. However complex those facts may be, and however difficult for China watchers to completely detach themselves from personal biases, it is believed that there is an ultimately knowable Chinese reality. The main task of China watching, by definition, should be about watching China. If China knowledge is indeed objective, scientifically testable, and professionally cumulative, then it would seem meaningless, if not self-indulgent, to dwell on questions such as what China knowledge is, who is producing it, how and for what purposes. ${ }^{23}$ Consequently, it is no surprise that few in the China-studies community have shown interest in such philosophical reflections and still fewer are keen on epistemological debates on China watching; ${ }^{24}$ such debates, standing apparently in the way of accumulating further knowledge on China, would appear not only unhelpful but needlessly polemic and divisive.

\section{A CASE FOR WATCHING CHINA WATCHING}

Critical epistemological reflection on the field of China's international relations is anything but trivial. At one level, some measure of selfreflectivity is not only necessary but also unavoidable. It pervades all literary works, as literature is always implicitly a reflection on literature itself. ${ }^{25}$ All forms of knowledge contain within themselves some conscious or unconscious, direct or indirect, autobiographical accounts of the knowing/writing self at either individual or certain collective levels. As evidenced in the selfimage of positivist knowledge in general, the very absence of critical selfreflection in China watching already denotes a particular way of speaking about itself, namely, as a cumulative body of empirical knowledge on China. The problem is that this scientistic self-understanding is largely uncritical and unconsciously so. If Pierre Macherey is right that what a work does not say is as important as what it does say, ${ }^{26}$ then this curious silence and unconscious- 
ness in the writing of China's rise needs to be interrupted and made more conscious, a process which Jürgen Habermas calls reflection. ${ }^{27}$

Besides, it seems impossible for China watching to watch only China. Aihwa Ong notes that 'When a book about China is only about China, it is suspect'. ${ }^{28}$ We may add that it is also self-delusional. China as an object of study does not simply exist in an objectivist or empiricist fashion, like a freefloating, self-contained entity waiting to be directly contacted, observed and analysed. This is not to say that China is unreal, unknowable or is only a ghostly illusion constructed entirely out of literary representation. Of course China does exist: the Great Wall, the Communist Party, and more than one billion people living there are all too real. And yet, to say something is real does not mean that its existence corresponds with a single, independent and fixed meaning for all to see. None of those aforementioned 'real' things and people beam out their meaning at us directly, let alone offer an unadulterated, panoramic view of 'China' as a whole. China's existence, while real, is better understood, to use Martin Heidegger's term, as a type of 'being-in-theworld'. ${ }^{29}$ The 'in-the-world-ness' is intrinsically characteristic of China's being, which always needs to be understood in conjunction with its world, a world which necessarily includes China-bound discourse and representation.

R. G. Collingwood once said that 'all history is the history of thought', meaning that no historian can speak directly of hard historical facts without reference to various thoughts about those facts. ${ }^{30}$ Likewise, insofar as China cannot exist meaningfully outside of language and discursive construction of it, no study of it is ever possible, let alone complete, without studying our thoughts about it. For this reason, echoing George Marcus and Michael Fisher's call for ethnography to 'turn on itself' and 'to create an equally probing, ethnographic knowledge of its social and cultural foundations, ${ }^{31}$ this book takes the representation of China (rather than 'China' itself) as its main object of study. It calls for a critical autoethnographic turn in China watching.

Certainly, there has been no shortage of study on Western representations of China. Alongside Western intellectual interest in this country is a longstanding tradition of documenting this interest, as evidenced in an extensive and diverse body of literature on Western images of China. ${ }^{32}$ If we also count the works on Western perceptions of Asia, the size of that literature is even more impressive. ${ }^{33}$ But this makes it all the more conspicuous that to date precious little has been said or written about contemporary China watching in global politics.

For instance, a large portion of the existing study is fixated either on past perceptions of China or perceptions of China's past. Historical investigation, valuable as it is, cannot substitute for an up-to-date account of contemporary Western knowledge on China. Meanwhile, most literature tends to limit its 
purview to 'non-scholarly' sources, such as government documents, official speeches, mass media, public opinion, travel writings, novels, documentaries and films. As a result, by design or by accident, scholarly literature is often able to escape attention.

Furthermore, even as some academic writings in historiographical, sociological, philosophical, cultural, and linguistic contexts have begun to be critically scrutinised, ${ }^{34}$ with few exceptions Western IR scholarship on China's rise continues to be overlooked. ${ }^{35}$ This is especially curious given that since the US consolidated its global dominance after World War II (WWII), IR discourses have become a main frame of reference for mainstream Western worldviews. ${ }^{36}$ Is this because discipline-based scholarship such as IR is better able to minimise the prejudice of Orientalism? Edward Said once claimed that 'interesting work is most likely to be produced by scholars whose allegiance is to a discipline defined intellectually and not to a "field" like Orientalism defined either canonically, imperially, or geographically'. ${ }^{37}$ However, it would be naïve, as Said himself would probably agree, to give the disciplines of IR and Political Science such benefit of the doubt. Though apparently defined intellectually rather than geographically, neither field is politically innocent or neutral. In fact, both remain largely an American/Western social science, whose implicit or unintended loyalty to the United States (US) is probably not dissimilar to that of Orientalism to Europe. $^{38}$ Indeed, precisely because these disciplines have now gained a false reputation of being value-free or scientifically objective, their contribution to Western construction of other societies could be all the more significant and lasting, thus deserving closer investigation. Failing that, it would be difficult for us to grasp the dynamics and complexities of contemporary Western representations of China in global politics.

No doubt, critical scholarship in the fields of IR and postcolonial studies has begun to problematise mainstream IR knowledge. Several important works in IR and cultural studies have examined at length the social construction of self/Other and the politics of representation in relation to the South, the East ('Near East'), and Asia. ${ }^{39}$ However, none of their focus is primarily on Western representations of China. Said's seminal work Orientalism, despite its sweeping subtitle 'Western Conceptions of the Orient', is concerned mainly with the Middle East. ${ }^{40}$ When sometimes Said is invoked in China analysis, it is often, perhaps justifiably, to probe China's own 'Orientalist' legacy (or in Xiaomei Chen's term, Occidentalism). ${ }^{41}$

Finally, where there exists useful criticism of Western IR discourses on China's rise, the criticism is often confined to empirical debate or concerned with factual or narrowly-conceived methodological matters related to specific works, claims, or issues. ${ }^{42}$ Most participants in such debates agree that there is a real China out there, and that the main problem with Western representa- 
tion lies in its misrepresentation, bias, or tainted perceptions: once such distortion is rectified, objective knowledge of China will be within reach. For example, having insightfully noted that 'Our uncertainties about China are as much a product of uncertainties about ourselves as they are about China', Brantly Womack then goes on to suggest that we should strive for an 'accurate understanding of China' through looking at the 'real' China and 'its internal dynamic'. ${ }^{43}$ To many, Womack's approach makes perfect sense: How could it be otherwise? And yet, appeals to 'reality' through more empirical research are ultimately of limited value. As Eric Hayot et al. put it, 'noting the discrepancy between reality and representation, as it applies to particular objects of discourse, no longer works as critique... critique has to acknowledge imagination as something more than a distorter of fact'. ${ }^{4}$

Understanding representation as 'something more' than an empirical matter is crucial, though this does not mean that empirical analysis has become irrelevant; it has not and will not. But if our critique of Western representations stays at an empirical level, it will be ultimately ineffective, if not misleading itself. For one thing, there is no compelling reason to suggest that our newer empirical data can serve as a more reliable base on which to build China knowledge. Moreover, as will be made clear in the book, the overall function of Western representations is self-imagination. For all their claims to scientific objectivity, they have not been primarily about presenting an empirically accurate picture of China in the first instance. As such, no amount of 'accurate' empirical facts or logical reasoning contrary to Western assumptions of China is likely to succeed in challenging those assumptions.

Consequently, in spite of the vast body of works that focus on Western images and representations of China, there is a glaring lack of critical analysis of contemporary Western thought on China's rise in the field of IR (broadly defined), a gap which this book aims to fill. The book is not interested in asking and whether or to what extent various forms of China knowledge accurately reflect 'Chinese reality'. Nor will it offer my own 'authentic' or 'objective' picture of that reality - so long as it is 'my own', it can be neither authentic nor objective. Instead, it will examine how various representations of 'Chinese reality', created under the guises of objective knowledge, are discursively and socially constructed, and how such constructions function in international relations theory and practice. Different from a conventional study of national image in foreign policy making, the main concern of the book is with a sociology of knowledge and politics of representation in relation to China watching.

To this end, the book draws attention to two dominant and recurring themes and assumptions on China's rise: the 'China threat' and 'China opportunity'. These themes may be variously termed as 'regimes of truth', 'metanarratives', or a certain 'style of thought', ${ }^{45}$ but here they are referred to 
as 'paradigms', a term made academically popular by Thomas Kuhn. ${ }^{46}$ More on the definition of the term will be said in a moment and in the next chapter. For now, like colonial discourse, a paradigm is 'a signifying system without an author'. ${ }^{47}$ In this sense, to illustrate my misgivings with the two China paradigms is not to pick on any individual scholars/authors or their specific works, even though in order to critically engage with those paradigms we have no choice but to rely on examples found in specific publications.

Also, these paradigms are not to be confused with any specific arguments or theoretical frameworks. A paradigm is a type of basic conceptual lens through which what can and cannot be known about a certain object of study is delineated, and from which certain specific arguments and theoretical frameworks can flow. Though the paradigms of 'China threat' and 'China opportunity' may be found more readily in the IR field of China watching, they are not the exclusive patents of IR scholars. To better illustrate these two paradigms, it is necessary to select the relevant literature on an eclectic basis. Coming within the purview of my analysis are, consequently, not just academic writings on China's foreign policy and international relations, but also other pieces in the 'China representation' puzzle such as media reports, commentaries, and official discourses.

As well as cutting across genre lines, the 'China threat' and 'China opportunity' paradigms are not confined within any particular geographical boundaries. True, the US has played a leading role in setting the agenda for Western perceptions of China's rise and much attention of the book will therefore be paid to the American discourse, but these paradigms are by no means distinctively American. This is why I use the designation 'Western' to cast a wider geopolitical net (and at the same time to leave out 'non-Western' sources to avoid making my enterprise too unwieldy). Of course, by 'Western' here I do not really mean 'Western' per se, whatever that term might mean. My source materials, in most cases, are drawn from English literature published in a few selected Western countries, notably the US, Britain, and Australia. Discourses from other Western countries, such as France and Germany, will not be examined, for the simple reason that their inclusion is beyond the scope and capacity of this single volume. Furthermore, even as I focus almost exclusively on English literature, I do not claim to do full justice to the inherently heterogeneous quality of China writings in those "Anglophone' locales. My understanding is that no matter how hard we try to narrow down our scope of investigation, we are bound to encounter still subtler spatial differences, contextual nuances, and temporal variations, which could well exist in the writings of the same author. Consequently, this study, its subtitle notwithstanding, does not claim to capture the full complexities or 'totality' of Western IR representations of China's rise, let alone China watching in general. 
We always need to maintain a vigilant suspicion of all forms of generalisation, but that suspicion should not turn into a paranoia about generalisation altogether. Without a certain degree of generalisation no analysis would be possible. Given its finite vocabulary, language is necessarily reductionist in its representation of an infinite world. It is in this context, as well as for stylistic reasons, that I have to employ such generalised, inherently problematic terms as 'China watching' and 'Western representations', even though I cannot emphasise enough that their specific usage here should never be misconstrued as an indictment to all China watchers or all Western representations of China.

\section{KNOWLEDGE, DESIRE AND POWER: A DECONSTRUC- TIVE/CONSTRUCTIVIST FRAMEWORK FOR ANALYSIS}

This book draws on deconstructive and constructivist approaches. Since it is not a book about either approach or about ontology/epistemology per se, it will not systematically engage with those theoretical issues except for the following outline of their relevance to this study. The deconstructive approach is employed to question the underlying dichotomy of reality/knowledge in Western study of China's international relations. My contention is that the paradigms of 'China threat' and 'China opportunity' are not 'true' (or 'false') representations of Chinese reality, but rather discursive strategies of Othering predicated on certain presuppositions and foreunderstandings in Western tradition, desire, and self-imagination. From a constructivist standpoint, I then argue that these paradigms are not mere word games or fanciful imaginations that have nothing to do with China. To the extent that they condition the way we give meaning to that country, they are socially constitutive of it, not least by shaping the way we deal with it in practice. Accordingly, my deconstructive analysis is not a mere textual exercise; it is concerned with the complex connections between these paradigms and Sino-Western interactions. These arguments will be fleshed out in the main chapters, but for now some explication of the theoretical and methodological underpinnings of this book is in order.

\section{Deconstructing Reality/Knowledge: Knowledge as Situated Interpreta- tion}

As a complex and controversial strategy in philosophical and literary criticism, deconstruction defies clear definition and explanation. At the risk of oversimplifying this slippery yet important term, I define the primary function of deconstruction as serving to expose the artificial and arbitrary nature of oppositions, dichotomies, and hierarchies that have been taken for granted 
in a certain discourse. In this way, deconstruction helps reveal the discursive and social practices of exclusion and marginalisation which are chiefly responsible for maintaining and reproducing the 'naturalness' of those binary oppositions and hierarchies. ${ }^{48}$ In mainstream IR discourses on China, one fundamental binary opposition is the dichotomy of reality and knowledge. According to this dualism, Chinese reality exists prior to and independent of China knowledge, with the latter derived from the former mainly through scientific research. Yet, this binary assumption about Chinese reality and China knowledge is deeply flawed and will be subject to deconstruction.

I submit that reality, or at least social reality, has no a priori or independent meaning outside of knowledge and discourse. If there appears to be an objective fact out there, that is because people who believe so already share a common discourse about that 'fact'. Thus, thought and reality are not two discrete, mutually exclusive categories as they appear. ${ }^{49}$ They are inherently interconnected. Indeed, 'interconnectedness' is not strong enough a word to depict their almost inseparable ontological existence, for it is only through knowledge and discourse that social reality comes into being and makes sense, just as it is only through light that things can become visible to our eyes. In the words of Maja Zehfuss, 'what we conceptualise as real is itself an effect of representations'. ${ }^{50}$ The world appears observable and meaningful to us never directly through itself, but only 'indirectly' through the 'light of interpretation' cast by texts, discourses, and language. If we merely stare at things without processing them through thought and language, our gaze will be like a blank look, unable to capture much meaning despite their clear presence in front of our eyes. As soon as we begin to describe what we have seen, that description must already be captive to language and prior knowledge. 'The world exists independently of language', notes David Campbell, 'but we can never know that (beyond the fact of its assertion), because the existence of the world is literally inconceivable outside of language and our traditions of interpretation'. 51

For instance, China as the world's most populous nation seems to be a self-evident fact both beyond doubt and beyond interpretation. Yet, such apparently objective, non-interpreted facts are not the primary concern of China watchers. No scholar is likely to make a career out of collecting and writing on such 'trivia' alone, just as no anthropologist would find it either stimulating or worthwhile to 'go round the world to count the cats in Zanzibar'. ${ }^{52}$ For us, often what matters is not 'pure' reality, but interpreted and contested reality. At issue here is not just whether China is the world's most populous nation, but also the 'so what?' questions: What that means (or often, will mean) for China and the world and what to do about it. As soon as meaning is at issue, commonly-agreed 'brute-facts' will be hard to come by. In the eyes of nineteenth-century missionaries, a populous China represented 
a promised land for religious conversion. During WWII, the US saw China's massive manpower as a great asset in fighting the Japanese. For business people whose worldview is inevitably defined by market and profit, China's vast population takes on a quality of enormous commercial opportunities. By contrast, for racists or racially sensitive observers, 1.3 billion Chinese may symbolise 'Yellow Peril' and amount to a 'China threat'. Clearly, none of these claims are stand-alone facts; as 'facts', they are always already a product of particular interpretation. Indeed, even the 'bare-bone' fact that China is the most populous nation is not entirely independent of language and interpretation, given that concepts such as nation and population are modern inventions and constructs rather than naturally existing categories. Consequently, social reality, which is what I mean by 'reality' or 'fact' throughout this book, is inherently discursive and interpretive, and interpretation cannot be disconnected from thought, knowledge, and language. To quote philosopher and linguist Wilhelm von Humboldt,

Man lives with his objects chiefly — in fact, since his feeling and acting depends on his perceptions, one may say exclusively - as language presents them to him. By the same process whereby he spins language out of his own being, he ensnares himself in it; and each language draws a magic circle round the people to which it belongs, a circle from which there is no escape save by stepping out of it into another. $^{53}$

Of course, to say that social reality is bound up with language and interpretation is not to argue that reality can be freely arranged into any number of discursive permutations or that one interpretation is as valid as another. We cannot access reality except through language, but this is not the same as saying that we cannot know anything beyond language per se, or that all knowing makes equal sense to everyone-were that the case, we in the academia might as well go home and find another line of work.

While reality is knowable only through interpretation, its knowing is not subject to the 'limitlessness of interpretation'. Like 'texts', reality imposes restraints upon its interpretation. ${ }^{54}$ To return to the earlier example, while China's population means different things to different observers under shifting circumstances, one cannot reasonably claim that there are now more people living in Australia than in China. While it is true that 'a person reading a text is himself part of the meaning he apprehends', ${ }^{55}$ the reader as a being-in-the-world does not and cannot interpret a given text or reality at will. All interpretation relies on language, but language is above all a social commodity, a carrier of the perceptions, attitudes, and goals of its society. ${ }^{56}$ Thus interpretation is by necessity always grounded in and constrained by certain 'preunderstandings' which in turn are conditioned on their culture, tradition, language, and a particular readership/audience that the relevant 
language entails. ${ }^{57}$ The 'life span' of an interpretation (or how far it can 'travel') depends on its communicability and social reception within its situated language and culture. While there are no pre-discursive or noninterpreted social facts and no formal limit on the range of interpretive possibility, in practice interpretation is rarely linguistically or textually random or anarchical, something we make up as we go along; rather, it is always intertextually situated in the sense that texts are dependent on and connected to other texts. In this sense, we need not fear the much-maligned relativist spectre of 'anything goes'; those who follow that path would soon realise that they cannot go very far. 'The historian', wrote E. H. Carr, 'is of his own age, and is bound to it by the conditions of human existence. The very words which he uses-words like democracy, empire, war, revolutionhave current connotations from which he cannot divorce them'. ${ }^{58}$ Like reading a text, our interpretation of reality is neither objective knowledge nor purely subjective speculation. Rather, it is a social text which necessarily speaks to other social texts. Such an undeniable and irreducible intertextuality constitutes what Said calls the materiality and worldliness of texts, so that those texts may effectively 'solicit[ing] the world's attention'. 59

In this way, while China knowledge (as in the form of the recurring themes of 'threat' and 'opportunity') is derived from interpretation, it is a particular form of worldly, intertextually situated interpretation that has thus far proved effective in soliciting the West's attention and capturing its selfimagination. It is often on this basis that China knowledge appears to be objective truth. However, that truth status should best be understood as an effect of its already shared and unquestioned interpretiveness. The intertextual contexts from which it arises have become so widely accepted that we tend to forget its 'original' status qua historically specific interpretations.

For this reason, Western representations of China's rise are not only interpretive, but also collectively and autobiographically so: they tell us less about China 'itself' (as a text) than about China watchers (as readers), their audience, and social, cultural and historical milieu. At least from Marco Polo onwards, the production of China knowledge has been subject to the logic and political economy of such situated intertextuality and worldliness. In The Chan's Great Continent, Jonathan Spence quotes an intriguing conversation between the fabled Venetian traveller and his Chinese host, the Kublai: 'When you return to the West', Kublai asks Marco Polo, 'will you repeat to your people the same tales you tell me?' Marco Polo gives no direct response. 'I speak and speak', he tells Kublai, '...but the listener retains only the words he is expecting.... It is not the voice that commands the story: it is the ear' ${ }^{60}$

Indeed, it is the ear of the audience, or the intertextual and worldly constraint, to which a China watcher needs to respond or endear oneself, whether consciously or not. To be sure, the intertextual context within which China 
knowledge is produced is not fixed, nor is it always a 'Western' context. Chinese voices, discourses and interpretations can, should, and have often been part of that interpretive process. In China Watcher, Baum tells a revealing story in the 1960s about a peculiar way in which China watchers, with Communist China off limits, often gazed at it from afar by interviewing mainland refugees in Hong Kong. He writes that:

Two particularly well-informed illegal aliens from Guangdong [known as Xiao Yang and Lao Yang] became more or less permanent fixtures at the Universities Service Centre in the late ' 60 s. They were interviewed so frequently and so intensively by center-based scholars that it became a standing joke among us - told only half in jest - that the vast majority of scholarly books, articles, and Ph.D. dissertations written about China during the Cultural Revolution decade, 1966-76, were based on information provided by these two individuals. My own 1975 book on the Four Cleanups, Prelude to Revolution, is no exception. ${ }^{61}$

This episode shows that a significant part of Western understanding of Chinese politics and society at that time might have come from two Chinese informants. It is safe to assume that what those informants told their Western interlocutors was not China per se either, but their situated interpretations of China or, more precisely, their interpretations of some specific vignettes of their own localised experience in China. In turn, those interpretations, if not already intentionally or unintentionally prompted or skewed to suit the needs of their Western interviewers, would certainly be subject to re-interpretation by the latter, in line with their worldliness and interpretive conventions. One source of such conventions, as American sociologist Richard Madsen notes, has been the writings of early Protestant missionaries to China, whose 'framework of assumptions about how to understand and what to do about China' in part laid the groundwork for today's secular China studies. ${ }^{62}$ Therefore, what can be and has been known about China is always already to some extent shaped by the intertextual situatedness of China watchers (including those who are Chinese). No one visits or studies China 'as entirely a stranger: we already know or think we know what is to be expected'. ${ }^{6}$ Veteran American journalist James Mann pithily described a similar process through which Western media coverage of China operates:

The biggest problem is that the media coverage of China tends merely to reinforce whatever is the reigning stereotype or image, or "frame," of China in any particular decade or era. In the 1950s, the coverage in the United States was of Chinese as disciplined automatons. In the 1980s, it was "China goes capitalist." In the early 1990s, it was "crackdown in China." Now, it's "China rising" (and "China gets rich"). Once an impression gels, then the extended press coverage-by which I mean, TV specials, newsmagazine covers, newspaper features-all either repeat the impression or at least play off it in some way or another. ${ }^{64}$ 
Explaining the problem, Mann believes that it is mainly those 'back in the home offices' such as producers, editors, and the like who help shape the China coverage according to the governing images of the day. ${ }^{65} \mathrm{He}$ probably could have added Western audience to that mix. Without the audience, or the ear, 'Rigorous research into specific aspects of contemporary China which does not capitalise on existing presumptions - the usual human rights, repressive regime, rampant capitalism etc frames-does not get past the niche market of China specialists, if it is published at all' ${ }^{66}$ In that case, many authors probably would never bother to begin with. Consequently, certain popular images will persist while alternative views struggle for attention. Some decades ago, the Australian journalist Peter Hastings hoped to write more reports on Asia but his boss, Sir Frank Packer (the father of the late Australian media tycoon Kerry Packer), frowned upon the idea: 'Nothing in it... Who wants to read about those places? ${ }^{67}$ Of course, in reality there was always much in it; it just happened that nothing there seemed to interest 'us'. Thus, like Asia, China's existence as an object of media curiosity or social inquiry from the outset owes a lot to this 'who'- the consumers in the marketplace of knowledge-and their expectations, presuppositions, foreunderstandings, and established self-imaginations.

\section{The Nexus of Knowledge/Desire: China Paradigms as Western Self- imagination}

Upon another look, Packer's question 'Who wants to read about those places' not only says much about the importance of readership and audience in the making of news, but also unwittingly reveals the central role of desire in the production and dissemination of knowledge. By desire I do not mean simply the 'desire to know' (epistemophilia), but also the myriad of human desires behind the desire to know. The received wisdom is that knowledge is an objective reflection of reality through reason, but as David Hume argues, 'Reason is, and ought only to be the slave of the passions and can never pretend to any other office than to serve and obey them'. ${ }^{68}$ At the root of knowledge is not just reason, but also desire. Desire fuels the need to acquire and produce knowledge, which in turn serves to rationalise and help fulfil desire. Hans Furth calls them the 'two sides of the same coin' ${ }^{69}$ Noting a similar 'interplay of knowledge and pleasure', Foucault argues that knowledge always needs to speak to desire, and desire must express itself in the form of knowledge. ${ }^{70}$ Desire is not just an attribute of the object of social study, but it also suffuses the process and end product of the study itself. It not just 'complicates an analyst's task' in knowledge accumulation; ${ }^{71}$ it is the precondition of such knowledge's social production and public consumption. 
To connect knowledge with desire is not to suggest that knowledge is reducible to any individual whim. Like language, knowledge is first and foremost a social property, whose reception qua knowledge must depend on its intersubjective appeal to collective emotion and social desire. Writings are driven by the desire to write, which in turn is conditioned on the desire to $\mathrm{read} / \mathrm{know}$ in the wider emotionally imagined community, a process governed throughout by the 'erotics of knowledge'. ${ }^{72}$ If it is through knowledge that reality is made meaningful, it is social desire that makes certain knowledge desirable and its production possible and profitable. To be sure, the role of desire in such a process is often invisible, silent, unconscious, and largely unacknowledged. That is because while ultimately knowledge is both a product of and for desire and emotion, in order to be worthy of the name, knowledge has to conceal its emotive trace. Or so it is believed.

Even with the concealment, modern science cannot deny its roots in the modern desire for certainty and identity. It is neither coincident nor ironic that Descartes, whose anxious desire for certainty finds expression in the 'Cartesian Anxiety' of an Either/Or (either there is a secure foundation upon which our knowledge can be based, or we will be engulfed in uncertainty and darkness), ${ }^{73}$ is credited with laying the foundation for modern science. It is not despite but because of the Cartesian Anxiety that Descartes 'discovered' human reason (cogito ergo sum, or 'I think, therefore I am') as the secure, indubitable foundation for certainty. From this emerges also the certain identity of modern man as the rational knowing subject, an identity which promises the ability to obtain objective knowledge about the world.

Yet objective certainty, however desirable or precisely because it is desir$a b l e$, is an illusory effect of desire. The desire for certainty may be satisfied only within desire and through the certainty of desire. When certainty is not within reach, the modern knowing subject, unable or unwilling to give up its quest, turns to the illusive certainty and comfort of what John Dewey called 'emotional substitute': 'in the absence of actual certainty... men cultivated all sorts of things that would give them the feeling of certainty'. ${ }^{74}$ Trust is one such feeling, which is not based on objective certainty, but cultivated through a process of 'emotional inoculation'. ${ }^{75}$ Fears and fantasies are two other forms of emotional substitute, especially useful for making sense of strangers. By fantasising about an uncertain other's assimilability and eventual transformation into the self, one can gain a sense of certainty. Alternatively, one may arrive at a sense of predictability by reducing that other to an already known prototype of menace. Either way, these emotional substitutes provide the much-desired antidote of certainty to the Cartesian Anxiety: either the other can be converted, or it must pose a threat. In this way, the initial uncertainty of the other translates into the certainty of an emotive either/or. 
As emotional substitutes for certainty, fears and fantasies have figured prominently in what Robert Young calls 'colonial desire', which regulates colonialists' encounters with and their knowledge of various unfamiliar Others. These emotions together make up an 'ambivalent double gesture of repulsion and attraction' towards the colonised. ${ }^{76}$ On the one hand, colonial desire finds people of other races and colours 'disgusting' and 'repulsive', hence an object of fear and paranoia. At the same time, colonial desire projects onto those (same) people some degree of 'beauty, attractiveness or desirability', 77 thus making them an exotic source of fantasy and wonder. According to Homi Bhabha, underlying such ambivalent structures of feeling is precisely the modern desire for certainty, identity and 'a pure origin'. 78 Thanks to this ever-present modern desire, the aforementioned ambivalent colonial stereotype is able to acquire 'its currency' and 'ensure[s] its repeatability in changing historical and discursive conjunctures'. In this sense, Orientalism is best seen as 'the site of dreams, images, fantasies, myths, obsessions and requirements'. ${ }^{79}$ What this latent form of Orientalist knowledge reveals is not something concrete or objective about the Orient, but something about the Orientalists themselves, their recurring, latent desire of fears and fantasies about the Orient. Indeed, only when imbued with such unconscious but persistent desire can Orientalism get 'passed on silently, without comment, from one text to another' ${ }^{80}$

Western knowledge of China's rise is precisely such a text that has been caught up in the silent emotive current. For example, the 'China threat' paradigm bears the stamp of fears, whereas the 'China opportunity' paradigm can be best seen as manifestations of modern fantasies. These emotions about China's rise are certainly not identical to the Orientalist colonial desire in the nineteenth century. For instance, the overtly sexual/racial connotation that once was a hallmark of old-style colonial desire is no longer prevalent in contemporary writings on China. What used to be some of the main obsessions in European colonial fears and fantasies, such as miscegenation and racial hybridity, have now been repackaged as issues of multiculturalism, norm diffusion, socialisation, and so forth. Still, a similar structure of colonial desire lives on; even the racial facet has not disappeared completely in contemporary China watching. ${ }^{81}$ Thus, to better understand the twin China paradigms, we need to put them in the context of (neo)colonial desire, and ask how they have more to do with the West's latent quest for certainty and identity than with the manifest search for empirical truth about 'Chinese reality'. If all social knowledge is yoked to some intertextuality and worldliness, much of the worldliness of the 'threat' and 'opportunity' discourses of China is then made up of the (renewed) fears and fantasies accompanying the Western modern desire and self-imagination. 


\section{Knowledge as Power, Theory as Practice, and Mutual Responsiveness}

All knowledge, insofar as it is a manifestation of desire, implies a power relationship with its desired object. 'Where there is desire, the power relation is already present'. ${ }^{82}$ Thus, knowledge loses its ostensible innocence and reveals its ties with power. As Foucault argues, 'there is no power relation without the correlative constitution of a field of knowledge', nor is there 'any knowledge that does not presuppose and constitute at the same time power relations'. Taken together, power and the production of knowledge 'directly imply one another' and are mutually dependent and reinforcing. ${ }^{83}$

The power/knowledge nexus has a constructivist import. Social knowledge cannot be an objective reflection of reality, but it is not merely a text disconnected from reality either. It is able to inform practice and help construct the reality it purports only to describe. If reality is subject to wordly interpretation, then the interpreting word is ultimately worldly with 'real-world' consequences. ${ }^{84} \mathrm{Jim}$ George notes that 'the process of discursive representation is never a neutral, detached one but is always imbued with the power and authority of the namers and makers of reality - it is always knowledge as power'. ${ }^{85}$ In a similar vein, Nicholas Onuf suggests that 'saying is doing: talking is undoubtedly the most important way that we go about making the world what it is'. ${ }^{86}$ With his 'Axis of Evil' utterance, for example, George W. Bush effectively told Americans that 'We can't go back to sleep again' ${ }^{87}$ In other words, something would have to be done (and indeed has been done).

In assuming knowledge as power and theory as practice, we should refrain from taking some self-serving short-cuts. As we are most closely attached to our own desire and most acutely aware of our knowledge, we might assume that the knowledge in the power/knowledge nexus is largely 'our' knowledge and the power mostly 'our' power. Such an assumption is evident, for example, in much of the mainstream IR literature on 'norm diffusion' and 'socialisation', which often implicitly privileges Western knowledge and power. But this ethnocentric reading of power/knowledge is problematic. Reality is subject to interpretation and construction by knowledge, ideas and norms, but it is almost always a result of $c o$-interpretation and $c o$-construction by a myriad of sources of knowledge as power. Western knowledge is no doubt a dominant source (let's assume for a moment that Western knowledge is singular); nevertheless, it is only one among many contenders in an increasingly democratic world of representation. Consequently, to argue for theory as practice is not to say that the world is mainly of our making. As Fredric Jameson reminds us, all history is contemporary history, but that 'does not mean that all history is our contemporary history'. ${ }^{88}$

At this point, the notion of knowledge as power needs to be tempered and complemented by an awareness of what I call 'mutual responsiveness' in the 
social world. Mutual responsiveness, as I have noted elsewhere, is a fundamental ontological condition of the world where various actors and 'objects' are intersubjectively connected. ${ }^{89}$ If in the end I cannot help making a foundational truth claim somewhere, this is it. Being part of this mutually responsive world, social research is not immune to this condition, a phenomenon identified by Anthony Giddens as the 'double hermeneutic'. ${ }^{90}$ That is, unlike in the natural sciences where the object of study does not seem to directly answer back, social knowledge has to live with the subjectivity and agency of its 'objects'. Indeed, that knowledge is always subject to interpretation, appropriation, disruption, alteration, and rejection by its 'objects'. Not only is our knowledge capable of constituting social reality, but the 'objects' of our knowledge, through their knowledge of their world, including their interpretations of both our knowledge and practice, are also capable of taking part in the co-construction of that reality. Thus the 'wholeness' of any social reality cannot be reduced to the unilateral constitutive effect of any particular discourse or knowledge, however powerful or universal it may appear. In this context, China is always more than the effect of Western representations of it. Its own subjectivities play various roles in the ongoing co-construction of itself and its international relations. Without taking this factor into account, our knowledge of China is at best partial knowledge. China knowledge, in the proper sense of the words, should after all be a kind of moral, intersubjective knowledge (or phronesis), ${ }^{91}$ a knowledge which so far remains underdeveloped and little-appreciated in the 'China's rise' literature.

\section{AN OVERVIEW AND BRIEF SELF-REFLECTION}

Informed by the deconstructive-cum-constructivist framework and mutual responsiveness perspective, this book will critically engage with the 'China threat' and 'China opportunity' paradigms. Chapter 2 illustrates how this dual mode of representation characterises Western perceptions of China's rise. In Chapter 3, I bring the deconstructive strategy to bear on this ambivalent bifocal lens in China watching. Its ambivalence towards China's rise says more about Western desire in general and Western fears and hopes in particular, and these China images are both predicated on and constitutive of Western self-imagination in terms of who 'we' are and who 'we' are not.

In Chapters 4 and 5, I probe into the nexus between knowledge, desire, and power in the 'China threat' paradigm and argue that the production of this particular body of knowledge has been linked to the political economy of fear. With a specific focus on the US, I will examine both how the 'China threat' paradigm is integral to the functioning of the military-industrial complex and military Keynesianism, and how military Keynesianism in turn contributes to the vibrancy of the 'China threat' knowledge industry. In short, 
this knowledge is both in the service of power and underpinned by it. Furthermore, often taken as objective truth, this paradigm informs a confrontational policy on China. By helping provoke nationalistic and realpolitik responses from China, such a policy makes the 'China threat' more likely in reality. In this way, as will be outlined in Chapter 5, the 'China threat' paradigm can become a self-fulfilling prophecy.

Chapters 6 and 7 then turn to the 'China opportunity' paradigm. In Chapter 6 , I argue that although the 'China opportunity' imagery often justifies a policy of engagement, its built-in normative objective of converting China is ultimately a false promise, which sets itself up for eventual disillusionment. In Chapter 7, I will examine how this 'China opportunity'-induced disillusionment is partly complicit in the recent hardline turn in Western policy on China. Chapter 8 concludes with a discussion on what China knowledge (and IR knowledge in general) means and entails epistemologically and methodologically. On the one hand, it urges China watchers to critically reflect on both the Western self-imagination upon which their China knowledge is predicated and the political economies of their knowledge production and application. On the other hand, it stresses the need to engage with Chinese subjectivities and discourses through ongoing dialogue. Together, it gestures towards a more self-conscious, ethically responsible way of knowing China as a being-in-the-world. Though the book does not prescribe any concrete advice to policy makers on how to make better China policy, some broad policy implications of this study should become clearer as one reads through.

Although or precisely because the book seeks to fill a gap in the existing literature on Western representations of China, it is itself intertextually connected to that literature and would not have been written without it. Its various perceived inadequacies provide the rationale for this study. Meanwhile, as shown through the references, the book also draws from other scholars a number of insights, such as the bifocal, emotive, autobiographical and political nature of Western representations of the Other. Together they become part of the intertextual background of this book. As a contingent, intertextually situated interpretation of a complex, fluid body of discourse, the book is not an 'objective' description of what China knowledge really is, for it cannot, nor can any other study, confront China knowledge 'in all its freshness as a thing-in-itself'. ${ }^{92}$ Given my particular focus and the limitation of space, I can only briefly reflect on my own interpretation. But it is worth noting that such self-reflection is crucial if my critique is to retain a level of intellectual healthiness, whose absence in mainstream Western literature on China's rise has prompted this study. Bearing this caveat in mind, we now turn to the substantive chapters. 